Editorial

\title{
Occupational therapy in times of pandemic: social security and guaranties of possible everyday life for all
}

\author{
Ana Paula Serrata Malfitano (D), Daniel Marinho Cezar da Cruz ${ }^{\mathrm{a}, \mathrm{b}}$ (D), Roseli Esquerdo Lopes ${ }^{\mathrm{a}}$ (D) \\ Editors of the Brazilian Journal of Occupational Therapy \\ ${ }^{a}$ Universidade Federal de São Carlos - UFSCar, São Carlos, SP, Brasil. \\ ${ }^{b}$ Wrexham Glyndwr University, Wrexham, United Kingdom.
}

How to cite: Malfitano, A. P. S., Cruz, D. M. C., \& Lopes, R. E. (2020). Occupational therapy in times of pandemic: social security and guaranties of possible everyday life for all. Cadernos Brasileiros de Terapia Ocupacional, 28(2), 401-404. https://doi.org/10.4322/2526-8910.ctoED22802

The pandemic caused by SARS-CoV-2 has required all professions to rethink and restructure their roles and modus operandi in order to deal with CoVID-19, reassuring and even reaffirming the power of professionals' contributions in face of the complex demands that we are living. The occupational therapy profession has been participating in this process through several initiatives, with the aim of caring for people daily life. We all share, in different ways of life, the necessity for social distancing, which has been imposed as a strategy in order to avoid the spread of the disease. Things are further complicated by the difficulties of the systems of sanitary vigilance and other epidemiologic considerations in the many affected countries. Nevertheless, we believe our role is central in the area of social security, according to social policies, especially approaching important social situations related to social inequalities involving people, groups and community's life with whom we work, especially in Brazil.

The World Federation of Occupational Therapists (WFOT) launched a public statement about the response of occupational therapists to the pandemic of CoVID-19, stating the profound impact on lives, health and wellbeing of individuals, families, and communities worldwide. They emphasize the role of occupational therapists in the everyday life of people, in the meaning and purposes of diary activities to their lives. In this way they highlight the relevance of strategic development to assist people to undertake their "occupations", as mentioned in their original document. In particular, it highlights the attention to mental health issues resulting from the pandemic, the access of assistive technologies and, in particular, 'Telehealth' as a new possibility for occupational therapy work (World Federation of Occupational Therapists, 2020).

In this same direction, the Brazilian Federal Council of Physiotherapy and Occupational Therapy (COFFITO) also regulated 'Telehealth', by Resolution number 516 (March 20 $0^{\text {th }}$ 2020). It authorizes 'Telehealth' as a possible method of working, with the purpose of carrying out actions for groups of the population with whom physiotherapists and occupational therapists work (Conselho Federal de Fisioterapia e Terapia Ocupacional, 2020a). New and novel modes of care (Malfitano \& Sakellariou, 2019) are being created, in order to minimize any disruption of the service delivery for some specific groups. The Brazilian Association of Occupational Therapists (ABRATO) 
manifested its concern related to work conditions and practices in the pandemic scenario; pointing out the contributions of occupational therapists and reporting their presence working in the front line of the pandemic in public Unified Health Care System (SUS), in the Social Care System (SUAS), in private care situations, and also in the non-governmental organizations, carrying out socio-sanitary, cultural, and humanitarian work (Associação Brasileira de Terapeutas Ocupacionais, 2020).

Focusing on individuals everyday lives, the Australian Association of Occupational Therapists published the guide "Normal life has been disrupted: managing the disruption caused by COVID-19" (Occupational Therapy Australia, 2020). This document was translated into Brazilian-Portuguese as "Orientaçóes práticas para rotinas saudáveis: aprendendo a lidar com as mudanças de rotina devido ao COVID-19" (Associação Cultural de Terapeutas Ocupacionais do Estado do Paraná, 2020), comprising relevant information for the organization of daily lives; highlighting the productivity, self-care, leisure, environment, routine and the ability to perform different occupational roles. This guide offers practical recommendations and suggestions for the management of diary activities during social isolation, associating orientations and suggestions to keep physical and mental health.

Considering everyday life, activities, doing and/or occupation as the locus of occupational therapists actions, some materials were produced targeting specific groups, such as: Mental Health (Universidade Federal de São Carlos, 2020a), Autism (Universidade Federal de São Carlos, 2020b), Ergonomics (Conselho Federal de Fisioterapia e Terapia Ocupacional, 2020b), among others. These publications have been written without the focus on occupational therapy, but with the participation of these professionals collaborating in authorship.

Recognizing the relevance of all contributions of these initiatives related to occupation in social isolation, we assert the need for occupational therapists to deal with the dimension of social inequality. It is necessary because, among other reasons, the spread of this virus in poor communities and peripheral areas of the cities, like in "favelas", brings more challenges. The instructions of 'staying at home' and 'social distancing' in this kind of context is related to the non-guarantee of the material maintenance of survival in those places where everyday there are already many risks to living safely (Associação Brasileira de Saúde Coletiva, 2020). This situation is also observed in some groups, such as homeless people, migrants, those living in shelters and prisoners. There are other effects from social isolation, such as the sad rise of domestic violence increasing alarmingly (Vieira et al., 2020), amongst other situations. In this context we advocate the participation of occupational therapists and other professionals based on the notion and defense of social security.

Social security is foreseen in the Brazilian Constitution, in its Article 194, involving integrating a cluster of initiatives to ensure the rights related to health, social insurance (retirement and workers' rights) and social care or welfare (Brasil, 1988). The relevance of social security is to ensure that only through the integration of social rights can we accomplish rights to social life for all; in other words, "Health" requires measures of "Social Insurance", guaranteeing means for survival of workers at least, regardless if they have disease or they are old; and, equally, it is necessary actions of "Social Care/Welfare", in order to secure access of social services to all citizens. Social security only becomes real in social programs and policies where these three policies (health, social insurance 
and social care) are present and their actions and services should be available to all citizens. Moreover, it is fundamental to highlight the relationship with "Education", (regulated by the Article 205 of the Brazilian Constitution). Education is connected with other social rights and sectors, and it is possible that through this integration, Education promotes other rights, because rights integration improves the well-being of humanity.

Therefore, occupational therapists need also to approach the role of professionals in the Social Care System, in the National Social Insurance, in the Prison System or Judiciary systems, in schools, in different sectors of community and communitarian and territorial work, in non-governmental organizations of public interest. It is more than ever necessary that we use our spaces, actions and voices to problematize what is happening in society, in terms of inequality of access to essential social benefits for all. If we are able to show this imbalance, we could have a major effect on the lives of so many people, consequently, enabling and enriching their everyday lives. First of all, we have to advocate for a quality of everyday life. For this purpose, the challenge is making real the core of social security, and also other aspects of welfare as a citizenship right and a duty of State and society. With this it is possible to comprehend the social dimensions of the social isolation/distance (Bezerra et al., 2020) and to advocate for our engagement in campaigns/actions founded on solidarity, which are requirements in this pandemic moment.

This statement links with the assumption that we can approach everyday life, activities, doing and occupations of different individuals, groups, and communities by social rights, especially by social security. In this way, the defense of social policies, notably from the Public Health, Social Insurance and Social Care/Welfare, integrate this time of pandemic in which we have been living. It should push occupational therapists beyond the adaption or organization of daily lives, the situation challenges occupational therapists to build relations between context, policies and lives.

To conclude, we affirm that the work of occupational therapy in the everyday life of all people only happens if we advocate for a possible quality of life for all, considering differences and power, which bring meaning and to life. If we assume the fight to reduce inequalities, it necessarily involves the advocacy for social security and our professional role in this field.

\section{References}

Associação Brasileira de Saúde Coletiva - ABRASCO. (2020). Coronavírus nas favelas: "É difícil falar sobre perigo quando há naturalização do risco de vida”. Rio de Janeiro: ABRASCO. Recuperado em 24 de abril de 2020, de https://www.abrasco.org.br/site/outras-noticias/saude-da-populacao/coronavirusnas-favelas-e-dificil-falar-sobre-perigo-quando-ha-naturalizacao-do-risco-de-vida/46098/

Associação Brasileira de Terapeutas Ocupacionais - ABRATO. (2020). Nota da ABRATO sobre a Portaria do Ministério da Saúde $n^{\circ}$ 639, de 02 de abril de 2020. Recife: ABRATO. Recuperado em 24 de abril de 2020, de https://www.facebook.com/abratonacional/

Associação Cultural de Terapeutas Ocupacionais do Estado do Paraná - ACTOEP. (2020). Orientaçôes práticas para rotinas saudáveis: aprendendo a lidar com as mudanças de rotina devido ao COVID-19. Curitiba: ACTOEP. Recuperado em 24 de abril de 2020, de https://www.facebook.com/actoep 
Bezerra, A. C. V., Silva, C. E. M., Soares, F. R. G., \& Silva, J. A. M. (2020). Fatores associados ao comportamento da população durante o isolamento social na pandemia de COVID-19. Ciência \& Saúde Coletiva. No prelo. Recuperado em 24 de abril de 2020, de https://preprints.scielo.org/index.php/scielo/preprint/view/123/173

Brasil. (1988). Constituição da República Federativa do Brasil de 1988. Diário Oficial [da] República Federativa do Brasil, Brasília. Recuperado em 24 de abril de 2020, de http://www.planalto.gov.br/ccivil_03/constituicao/constituicao.htm

Conselho Federal de Fisioterapia e Terapia Ocupacional - COFFITO. (2020a). Resolução no 516, de 20 de março de 2020. Dispóes sobre Teleconsulta, Telemonitoramento e Teleconsultoria. Diário Oficial [da] República Federativa do Brasil, Brasília. Recuperado em 24 de abril de 2020, de https://www.coffito.gov.br/nsite/?p=15825

Conselho Federal de Fisioterapia e Terapia Ocupacional - COFFITO. Conselho Regional de Fisioterapia e Terapia Ocupacional da 15a . Região - CREFITO-15. (2020b). Orientaçóes ergonômicas para trabalho: home office. Brasília: COFFITO. Recuperado em 24 de abril de 2020, de https://www.coffito.gov.br/nsite/wp-content/uploads/2020/04/20200326_ErgonomiaA.pdf

Malfitano, A. P. S., \& Sakellariou, D. (2019). Care and occupational therapy: what kind of care definition do we have? Cadernos Brasileiros de Terapia Ocupacional, 27(3), 681-685.

Occupational Therapy Australia - OTA.(2020). Normal life has been disrupted: managing the disruption caused by COVID-19. Fitzroy: OTA. Recuperado em 24 de abril de 2020, de https://otaus.com.au/publicassets/af469002-6f6a-ea11-9404005056be13b5/OT\%20Guide\%20COVID-19\%20March\%202020.pdf

Universidade Federal de São Carlos - UFSCar. Laboratório de Terapia Ocupacional e Saúde Mental - La Follia. (2020a). Cuidando da saúde mental em tempos de coronavírus. Recuperado em 24 de abril de 2020, de https://www.informasus.ufscar.br/wp-content/uploads/2020/04/coronavirus_saudemental2.pdf

Universidade Federal de São Carlos - UFSCar. Laboratório de Terapia Ocupacional e Saúde Mental - La Follia. (2020b). Autismo: em tempos de coronavirus como podemos ajudar? Recuperado em 24 de abril de 2020, de https://www.informasus.ufscar.br/wpcontent/uploads/2020/04/CONSCIENTIZAÇÃO-AUTISMO-E-CORONAVIRUS.pdf.

Vieira, P. R., Garcia, L. P., \& Maciel, E. L. N. (2020). Isolamento social e o aumento da violência doméstica: o que isso nos revela? Revista Brasileira de Epidemiologia, 23, e200033. PMid:32321005. http://dx.doi.org/10.1590/1980-549720200033.

World Federation of Occupational Therapists - WFOT. (2020). Public Statement - Occupational Therapy Response to the COVID-19 Pandemic. London: WFOT. Recuperado em 24 de abril de 2020, de https://www.wfot.org/about/public-statement-occupational-therapy-response-to-the-covid-19pandemic\#entry:22326 